\title{
LOS CAMINOS POSIBLES DEL \\ LIBERALISMO POSREVOLUCIONARIO
}

\section{THE POSSIBLE WAYS OF THE POST-REVOLUTIONARY LIBERALISM}

\author{
Manuel Carbajosa Aguilera \\ Universidad Pablo de Olavide de Sevilla \\ manuelcarbajosa@hotmail.com
}

Recibido: agosto de 2018

Aceptado: noviembre de 2018

Palabras clave: Revolución francesa, burguesía, libertad, liberalismo posrevolucionario.

Keywords: French Revolution, middle class, freedom, post-revolutionary liberalism

Resumen: La Revolución francesa supuso un impacto en todos los ámbitos de la vida. La clase social triunfante, la burguesía, se asomó a los abismos que la propia Revolución había creado, viendo peligrar su proyecto de conquista social. Tras el Terror se inicia un período de reflexión y repliegue, en el que la burguesía deja atrás su estrategia revolucionaria para asentar los logros obtenidos: había empezado el liberalismo conservador.

Abstract: The French Revolution supposed an impact in all the areas of the life. The social triumphant class, the bourgeoisie, appeared to the abysses that the own Revolution had created, seeing being in danger his project of social conquest. After the Terror it begins a period of reflection and doubling, in that the middle class leaves behind his revolutionary strategy to seat the obtained achievements: the conservative liberalism had begun.

«[...] penetro un poco más en la vida social y la denuncio.

Y la denuncio porque vengo del campo y creo que lo más importante no es el hombre».

Federico García Lorca, Poeta en Nueva York.

\section{Los delirios de la libertad y la orfandad contemporánea}

Tras la caída del Terror, las nuevas élites que emergen de la Revolución francesa comienzan a tomar conciencia de los límites del proceso revolucionario, iniciando un período de reflexión fruto del cual va a nacer, tras un largo camino, el gobierno representativo en Francia ${ }^{1}$.

1. Vid. Laquièze, Alain: Les origines du régime parlementaire en France (1814-1848), París, Presses Universitaires de France, 2002. 
Por lo pronto la clase que ha triunfado con la Revolución, la burguesía, ha comprobado que, paralelo al abismo que por la derecha representan el Antiguo Régimen y la reacción, ha surgido un nuevo precipicio por la izquierda: la Revolución ha manifestado una deriva radical que, precipitada al descontrol, puede devorar a sus propios hijos. Si 1789 fue el símbolo de un liberalismo de derribo, en 1793 todo es arrastrado en aras de la virtud revolucionaria por el abismo anárquico de la radicalidad, de la ebriedad de la razón, de la absolutización de la libertad. Como escribe Finkielkraut «al intentar derrocar al padre, han matado a la madre»; de este modo, la liberación inicial se pierde en la confusión y el extravío². Para Bénichou:

"La fe filosófica constituida en gobierno adquiere forma homicida; en presencia de las dificultades que amenazan toda revolución, fulmina no solo contra sus enemigos, sino contra el principio mismo del que ha nacido y que pretendió oponer al dogma religioso: el de una actuación libre y diversa del espíritu» ${ }^{3}$.

Irrumpe la estrategia política burguesa de rechazo al pueblo que, acusado de carecer de razón, es señalado como causante de ese proceso descontrolado e irreflexivo de disolución social. El objetivo a partir de

2. Finkielkraut, Alain: La défaite de la pensée, París, Gallimard, 1987 (seguimos la traducción en castellano de Joaquín Jordá, La derrota del pensamiento, Barcelona, Anagrama, $5^{\text {a }}$ edición, septiembre de 1994, [1ª ed. octubre 1987], p. 26).

3. Bénichou, Paul: Le sacre de l'écrivain, 17501830. Essai sur l'avènement d'un pouvoir spirituel laïque dans la France Moderne, París, Corti, 1973 (trad. al castellano de Aurelio Garzón del Camino, La coronación del escritor, 1750-1830. Ensayo sobre el advenimiento de un poder espiritual laico en la Francia moderna, México, Fondo de Cultura Económica, 1981, p. 59). ahora será neutralizarlo de la vida públi$\mathrm{ca}{ }^{4}$.

Toda aquella generación ha aprendido que el sueño de la razón produce monstruos: la libertad absoluta y abstracta conduce al Terror, a la anarquía. El individuo, despojado por la absolutización de la razón de todos sus referentes, se ha encontrado con la desolación y el vacío de la modernidad. Han quedado barridos los viejos refugios, aquellas referencias perennes y seguras, que, como maderos, habían salvado a los náufragos de todas las épocas anteriores, ante lo cual el hombre contemporáneo se ve abocado a caminar a tientas sobre los abismos de su indeterminación, del vaciamiento de su alma y de la relativización del mundo. La libertad del 89, luminosa y triunfante, ha quedado ahogada en aquelarres de guillotinas y persecuciones, dejando a la persona desnuda bajo el imperio de una razón absoluta y deshumanizada, insensible ante el horror de aquellos crímenes cometidos al albur del espíritu de la épo$\mathrm{ca}^{5}$. Depravaciones de uno u otro signo

4. Vid p. ej. Guillemin, Henri: Silence aux pauvres! Libelle, París, Arléa, 1989 (trad. al castellano por Juan Vivanco, ;Los pobres, a callar! Libelo, Barcelona, Grijalbo Mondadori, 1997).

5. Vid. Starobinski, Jean: 1789. Les Emblèmes de la Raison, París, Flammarion, 1973 (trad. al castellano de José Luis Checa Cremades, 1789, los emblemas de la razón, Madrid, Taurus, 1988, pp. 27 y ss.). Schenk, H. G.: The Mind of the European Romantics. An Essay in Cultural History, Londres, Constable \& Co., 1966 (trad. al castellano por Juan José Utrilla, El espíritu de los románticos europeos. Ensayo sobre historia de la cultura, México, Fondo de Cultura Económica, 1983, pp. 25, 35 y ss.). Vovelle, Michel: La mentalité révolutionnaire. Société et mentalités sous la Révolution française, París, Messidor-Éditions Sociales, 1985 (trad. al castellano de Rafael Santamaría, La mentalidad revolucionaria, Barcelona, Crítica, 1989, cuaderno central de ilustra- 
se sucederán a lo largo de la nueva era. En aras de la libertad, se sacrifican los referentes de la inmutabilidad, dejando al hombre inerme ante la angustia del vacío contemporáneo. Como escribe Innerarity: "La libertad tiene un carácter abismático. La condición de posibilidad de su infinitud es una indeterminación que puede ser experimentada como un vacío absoluto» 6 . Benjamin Constant testimonia en 1790 aquella sensación común de desarraigo:

«Siento más que nunca la nada de todas las cosas, hasta qué punto todo promete y nada se cumple, hasta qué punto nuestras fuerzas están por encima de nuestros destinos y hasta qué punto esta desproporción debe hacernos desgraciados. Esta idea, que encuentro justa, no es mía [...]. Pretende que Dios, creador nuestro y de todo lo que nos rodea, ha muerto antes de haber terminado su obra; que tenía los más bellos y vastos proyectos del mundo y los mayores medios; que había comenzado a utilizar varios de estos medios y que, a mitad del trabajo, murió; que en el momento presente todo se encuentra hecho para una finalidad que ha dejado de existir, y que nosotros en particular nos sentimos destinados a algo de lo que no nos hacemos la menor idea [...] ${ }^{7}$.

ciones, ilustración $\mathrm{n}^{\circ}$. 1: Robespierre guillotinant le bourreau après avoir fait guillotiner tous les Français). Mayer, Arno J.: The Furies.Violence and Terror in the French and Russian Revolutions, Princeton and Oxford, Princeton University Press, 2000 (trad. al castellano de Víctor Lucea Ayala, Las Furias: violencia y terror en las revoluciones francesa y rusa, Zaragoza, Prensas de la Universidad de Zaragoza, 2014, pp. 197 y ss.).

6. Innerarity, Daniel: Hegel y el romanticismo, Madrid, Tecnos, 1993, pp. 54-55.

7. Carta de Benjamin Constant a Mme. de Charrière, 4 de junio de 1790, apud Starobinsky, op. cit., pp. 136-137. La carta en Rudler, Gustave: La Jeunesse de Benjamin Constant, 1767-1794. Le disciple du XVIIIe siècle. Utilitarisme et pessimisme. Mme. de Charrière. D'après de nom-
Decenios después Guizot sigue evocando la ruptura revolucionaria:

« [...] si, después de semejante sacudida, el hombre vuelve su mirada hacia la historia de los tiempos pasados, le cuesta trabajo reconocerla. Lo que ahora ve, no lo veía antes; lo que antes veía, ya no es tal como lo había visto; los hechos se le aparecen bajo un rostro desconocido y le hablan otro lenguaje. [...] por todas partes se abren ante él perspectivas desconocidas. El espectáculo sigue siendo el mismo, pero es otro el espectador y ocupa otro lugar. A sus ojos todo ha cambiado» ${ }^{8}$.

Y deja constancia de la inseguridad contemporánea:

«Hemos sido empujados hacia unos caminos que no sólo son nuevos, sino que son sin cesar caminos rotos y pueden resultar diferentes. Todas las teorías, todas las prácticas se han desplegado y han combatido ante nuestros ojos. Hechos de todo tipo se nos han presentado bajo una multitud de aspectos. La naturaleza humana se ha visto desafiada muy a fondo y ha quedado al desnudo, por así decirlo, en todos los elementos que la constituyen. Las cosas, los hombres; todo ha cambiado de sistema $y$ ha sufrido diferentes combinaciones; y el observador, al cambiar sin cesar de punto de vista, ha observado un espectáculo que cambiaba sin cesar a su alrededor» ${ }^{9}$.

Ante los abismos, y en ausencia de referentes a los que sujetarse, surge el vér-

breux documents inédits, París, Armand Colin, 1909, pp. 376-377.

8. Guizot, François: Histoire des origines du gouvernement représentatif en Europe, París, Didier, 2 vols., 1851 (trad. al castellano en un volumen de Marceliano Acevedo Fernández, Historia de los orígenes del gobierno representativo en Europa, Oviedo, KRK, 2009, p. 45).

9. Guizot, Historia de los orígenes del gobierno representativo en Europa, op. cit., p. 58. 
tigo. Es el caso del vértigo radical que para toda aquella generación supuso la culminación del proceso de sustitución de Dios por el hombre como cúspide de autoridad, que los marcará no sólo a ellos sino a las generaciones posteriores. Ninguna idea fue tan radicalmente desoladora como ésa y no son pocos los que, junto a sus reflexiones políticas, mostraron una significativa preocupación por el hecho religioso en la sociedad contemporánea - aunque tampoco perdamos de vista su instrumentalización por parte de las Iglesias ante la pérdida de los privilegios y de su representación, lo que a la larga marca la contemporaneidad con la perversa dialéctica entre orden-tradición-Dios versus libertad-progreso-ateísmo ${ }^{10}$ —. Según Guizot, a partir de 1789 « [...] la fe y la esperanza en el hombre reemplazaban a la fe y la esperanza en Dios» ${ }^{11}$. Madame

10. Vid. p. ej. Bénichou, La coronación del escritor, op. cit., passim. Del mismo autor vid. también, Le temps des prophètes. Doctrines de l'âge romantique, París, Gallimard, 1977 (trad. al castellano de Aurelio Garzón del Camino, El tiempo de los profetas. Doctrinas de la época romántica, México, Fondo de Cultura Económica, 1984). Hazard, Paul: La crise de conscience européenne, 1680-1715, París, A. Fayard, 1961 (trad. al castellano de Julián Marías, La crisis de la conciencia europea (1680-1715), Madrid, Alianza, 1988, pp. 368 y ss.). Díez del Corral, Luis: El liberalismo doctrinario, Madrid, Centro de Estudios Constitucionales, $4^{\text {a }}$. ed., 1984 [ $1^{\text {a }}$ ed. 1945], p. 37. Mayer, op. cit., pp. 465-503. Álvarez Tardío, Manuel: "Dieu et liberté: la alternativa del catolicismo liberal en el ochocientos", en Historia y Política, no. 3 (2000), pp. 7-30.

11. Guizot, François: De la démocratie en France, París, Plon-Víctor Masson, 1849 (traducción, introducción y notas de Dalmacio Negro Pavón, De la democracia en Francia, Madrid, Centro de Estudios Constitucionales, 1981, p. 192). Vid. Mathiez, Albert: Les origines des cultes révolutionnaires (1789-1792), París, Société Nouvelle de Librairie et d'édition, 1904 (seguimos la edi- de Staël se resiste a admitir este horizonte de desamparo:

«Todos los sentimientos desinteresados, todas las ideas elevadas, todos los afectos profundos, tienen un carácter religioso; cada cual entiende a su modo esta revelación del alma; pero no existe emoción alguna, tierna y generosa, que no nos haga desear otro mundo, otra vida, una región más pura donde la virtud encuentra su patria» ${ }^{12}$.

Manipulado como argumento beligerante por la reacción, rechazado por los delirios de la Revolución, la orfandad de Dios será una de las espinas permanentes de la contemporaneidad. En última instancia, Dios ya no será repuesto en el lugar que ocupaba, ni tan siquiera por los tradicionalistas quienes, a pesar de su mística del pasado, han quedado rendidos, en su odio a la modernidad, a un idealismo de nuevo cuño, a una concepción del mundo radicalmente nueva: el alma de la nación ${ }^{13}$. Tan solo los artistas, en su búsqueda estético-existencial, lograrán desvelar el misterio último del hecho religioso en el sentimiento de piedad, esencia de la idea de dignidad de la persona y semilla germinal de los derechos humanos ${ }^{14}$. Mientras

ción, traducción, estudio preliminar y notas de Francisco Javier Ramón Soláns, Los orígenes de los cultos revolucionarios (1789-1792), Zaragoza, Prensas de la Universidad de Zaragoza, 2012).

12. De Staël, Mme. [Anne-Louise Germaine Necker]: Delphine, 1803, en Ouvres complètes, París, 1820-1821, t. VII, p. 257 apud Bénichou, La coronación del escritor..., op. cit., p. 214.

13. Vid. Finkielkraut, op. cit., pp. 28 y ss. Schenk, op. cit., p. 275.

14. Vid. Schenk, op. cit., pp. 96 y ss. Bonnefoy, Yves: Goya, les peintures noires, Burdeos, William Blake \& Co., 2006 (trad. al castellano de Patricia Martínez, Goya. Las pinturas negras, Madrid, Tecnos, 2018). Sánchez-Mejía, María Luisa: Benjamín Constant y la construcción del 
tanto y frente a una reacción que había extremado su intolerancia ${ }^{15}$, una minoría moderada abogará por una razón contextualizada y una Iglesia ilustrada clamando entre sordos. Por ejemplo, en aquella España, donde la impronta religiosa era incontestable ${ }^{16}$, Alberto Lista escribe: «Nada ha hecho más daño a la religión que el espíritu de intolerancia a que deben su origen las instituciones inquisitoriales» ${ }^{17}$, afirmando que «El Evangelio no es un tratado de política constitucional, sino de la moral más perfecta» ${ }^{18}$. Ante esa parte del clero que se ha entregado al fanatismo, Lista reflexiona:

«Ministros de paz convertidos en jefes de partidas alucinadas; monjes que han tomado el sable para reconquistar la coguIla; fanáticos que sólo respiran sangre y venganzas contra las luces y conocimientos del siglo; furibundos para quienes el mundo no existe si no hay en él Inquisición; ¿son éstos

liberalismo posrevolucionario, Madrid, Alianza, 1992, pp. 212-213.

15. Vid. Mayer, op. cit., pp. 63-90; 365-417; 465-503.

16. Vid Herrero, Javier: Los orígenes del pensamiento reaccionario español, Madrid, Cuadernos para el diálogo-Edicusa, 1973, pp. 35 y ss. González Cuevas, Pedro Carlos: Historia de las derechas españolas. De la Ilustración a nuestros dias, Madrid, Biblioteca Nueva, 2000, pp. 19-20, 39 y ss. Portillo Valdés, José María: Revolución de nación. Orígenes de la cultura constitucional en España, 1780-1812, Madrid, Centro de Estudios Políticos y Constitucionales, 2000. Lista, Alberto: "Del fanatismo y de la intolerancia, su compañera inseparable", en El Censor, t. IX, $\mathrm{n}^{\circ}$. 49 (7 de julio de 1821), pp. 73-75.

17. Lista, Alberto: "Del fanatismo servil", en $E l$ Censor, t. XVII, no. 101 (6 de julio de 1822), p. 334.

18. Vid. Lista, Alberto: "Italia", en El Censor, t. IV, no ${ }^{\circ} 21$ (23 de diciembre de 1820), p. 195. los que se encargan de restituir a la fe de Jesucristo su esplendor?»19.

Su conclusión es rotunda: « [...] el Cielo no se gana con furores, ni la religión se defiende con asesinatos ${ }^{20}$, condenando aquel espíritu de cruzada:

«Estaba reservado a nuestros días el mayor de los absurdos, cual es, sustituir al signo de las libertades públicas la imagen de nuestro Salvador, que declaró poco antes de morir que su reino no era de este mundo. ¡Sacrílegos! Han arrancado del Santuario el signo y la imagen de la redención para convertirle en antorcha de guerra civil y en escándalo y desventura ${ }^{21}$.

Los nuevos dioses han aplastado al hombre contemporáneo con nuevas superioridades —cadenas nuevas, desprecios eternos-, con un agravante: la persona ha sido barrida por la razón. Esa tierra prometida revela nihilismo y crueldad, haciendo de la libertad un espejismo y de la igualdad una utopía para los desheredados —qué luces eran aquéllas, legitimadas por el Terror; qué luces son éstas, legitimadas por la bolsa de monedas-. A los despojados del Reino de la libertad y la razón no les quedará ni el consuelo de considerarse hijos de Dios, ni tan siquiera el anhelo del Reino de los Cielos²2: la sola evocación divina los expulsaba a los rincones de la existencia acusados de ignorantes por unas élites que instrumentalizan el recurso religioso: unos, alegan-

19. Lista, "Del fanatismo servil", en El Censor, XVII, 101, op. cit., p. 335.

20. Ibid.

21. Lista, "Del fanatismo servil", en El Censor, XVII, 101, op. cit., pp. 335-336 (resaltado en el original).

22. Vid. Maritain, Jacques: The Range of Reason, Nueva York, Scribner, 1952 (trad. al castellano de Alberto Luis Bixio, El alcance de la razón, Buenos Aires, Emecé, 1959, pp. 292-314). 
do pertenencias de abolengo; otros, más tarde, considerando aquello como un opio inaceptable.

El materialismo creciente — «ávido, brutal y desenfrenado» ${ }^{23}$ - que trae la Revolución francesa y la Revolución industrial, alerta a los pensadores. La Revolución industrial cosifica al individuo, haciéndolo una pieza más de un engranaje destinado a maximizar los beneficios al menor coste posible. Comparada con la Revolución francesa, ésta resulta zigzagueante y desnortada, en una búsqueda imprecisa de fórmulas capaces de arraigar el nuevo espíritu del siglo sobre la herencia de los tiempos; imprecisión que contrasta con la claridad de hierro de la propuesta estructural de la Revolución industrial ${ }^{24}$. Los nuevos notables habían enarbolado libertades, pero los usos seguían siendo feudales para los excluidos. La idea de que la propiedad y los talentos iban a gobernar la nueva sociedad resultaba por tanto una quimera y serán únicamente los detentadores de la gran propiedad, con independencia de los medios utilizados para adquirirla, los que coparán las altas esferas del poder. La élite esgrimirá la respetabilidad de clase y, envueltos en la lógica del desprecio, ignorarán a mitad de siglo las advertencias de Tocqueville:

«Miren lo que pasa en el seno de esas clases obreras que hoy -lo reconozcoestán tranquilas. Es verdad que no están atormentadas por las pasiones políticas propiamente dichas, en el mismo grado en que lo estuvieron en otro tiempo, pero ¿no ven ustedes que sus pasiones se han convertido, de políticas, en sociales? ¿No ven ustedes que, poco a poco, en su seno se extienden unas opiniones, unas ideas

23. Vid. Guizot, De la democracia en Francia, op. cit., p. 194.

24. Vid. p. ej. Schenk, op. cit., pp. 52 y ss. que no aspiran solo a derribar tales leyes, tal ministerio, incluso tal gobierno, sino la sociedad misma, quebrantándola en las propias bases sobre las cuales descansa hoy? ¿No escuchan ustedes lo que todos los días se dice en su seno? ¿No oyen ustedes que allí se repite sin cesar que todo lo que se encuentra por encima de ellas es incapaz e indigno de gobernarlas, que la división de los bienes hecha hasta ahora en el mundo es injusta; que la propiedad descansa sobre unas bases que no son las bases de la equidad? ¿Y no creen ustedes que, cuando tales opiniones echan raíces, cuando se extienden de una manera casi general, cuando penetran profundamente en las masas, tienen que traer, antes o después -yo no sé cuándo, yo no sé cómo-, pero tienen que traer, antes o después, las revoluciones más terribles?» ${ }^{25}$.

Las tempranas percepciones de Sismondi, de Coleridge o de Southey inauguran una corriente crítica con el modelo de modernidad impuesto. Un siglo después, en su reflexión esencialmente moral por esencialmente religiosa, esperanzadora y auroral, María Zambrano afirmará: «Los postulados espirituales del liberalismo no pueden realizarse con la economía liberal» ${ }^{26}$. A poniente de siglo, Isaiah Berlin escribe: «[...] la libertad total para

25. Vid. Tocqueville, Alexis de: Souvenirs, París, Calmann Lévy, 1893 (trad. al castellano de Marcial Suárez, Recuerdos de la Revolución de 1848, Madrid, Trotta, 1994, p. 36). También en Ponteil, Félix: 1848, París, Armand Colin, 1837 (trad. al castellano de Jesús Castellote López, La Revolución de 1848, Madrid, Zyx, 1966, p. 32). El discurso completo en Tocqueville, Mme. de (ed.), Euvres complètes d'Alexis de Tocqueville, t. IX: Études économiques, politiques et littéraires par Alexis de Tocqueville, París, Michel Lévy, 1866, pp. 520-535.

26. Vid. Schenk, op. cit., pp. 52 y ss. Zambrano, María: Horizonte del liberalismo, Madrid, Morata, 1996 [1 $1^{\text {a }}$ ed. 1930], p. 261. 
los lobos es la muerte para los corderos, la libertad total para los poderosos, los dotados, no es compatible con el derecho a una existencia decente de los débiles y menos dotados», por eso la igualdad exige limitar la libertad de los que quieren dominar «[...] para dejar espacio al bienestar social, para alimentar al hambriento, vestir al desnudo, cobijar al que no tiene casa, para dejar espacio a la libertad de otros, para que pueda haber justicia o equidad» ${ }^{27}$.

A las nuevas élites, la moral, que puede cuestionar su ejemplaridad social, les resulta un obstáculo para la maximización de sus objetivos y, empleando la filosofía industrial, la decantan bajo la acusación de inutilidad frente al único baremo válido: la propiedad. Su nueva Biblia de lunes a sábado es el libro de cuentas y resultados; el domingo quedará simplemente para guardar las apariencias. Se estaba imponiendo la sociedad capitalista. Retomando a María Zambrano, desde el principio se sacrificaron la igualdad y la fraternidad en aras de la libertad:

"Se dividió la humanidad por no perder la conquista. Unos perseguirían la superación, el récord; otros pagarían por ellos el tributo a la necesidad. Unos, afán heroico; otros, trabajoso esfuerzo sin horizontes.

Y ya tenemos otra vez la contradicción. El liberalismo se asienta sobre la escla-

27. Berlin, Isaiah: The Crooked Timber of Humanity: Chapters in the History of Ideas, Londres, John Murray, 1990 (trad. al castellano de José Manuel Álvarez Flórez, El fuste torcido de la humanidad. Capitulos de historia de las ideas, Barcelona, Península, 1992, p. 31). Vid. también Droz, Jacques: Europe between Revolutions, 1815-1848, Londres, Collins Sons, 1967 (trad. castellano de Ignacio Romero de Solís, Europa: Restauración y Revolución, 1815-1848, Madrid, Siglo XXI, 11 ${ }^{\mathrm{a}}$ ed., 1993 [ $1^{\text {a }}$ ed. 1974], pp. 1-2; 36 y ss.). vitud, y solo sobre ella puede alcanzar su perfección» ${ }^{28}$.

En este contexto radicalmente nuevo, el hombre empieza a otear que su individualidad no puede reducirse a la abstracción, sino que tiene también una indisoluble dimensión sensible y social. Desde el crepúsculo de la llustración se había iniciado el camino hacia la interioridad sensible de un romanticismo que irá brotando en el espíritu del siglo29. Goya lo había advertido aterrado: las luces aparentes de la realidad, acicaladas conforme a la época, ocultaban, tras su máscara seductora, la negritud brujeril de su siniestro reverso ${ }^{30}$. Andando el tiempo, el hombre contemporáneo empezará a intuir que las únicas luces posibles habrán de reconciliarse con los arraigos no racionales de la existencia ${ }^{31}$.

\section{Reflexión y reconstrucción: el replieque de la libertad.}

¿Es el Terror una consecuencia natural o por el contrario una degeneración de la Revolución de las luces? Progresismo y conservadurismo se encargarán de rotu-

28. Zambrano, op. cit., pp. 234-235.

29. Vid. Vivanco, Luis Felipe: Moratín y la Ilustración mágica, Madrid, Taurus, 1972, pp. 214 y ss.

30. Bonnefoy, op. cit., passim. Béjar, Helena: $L a$ cultura del yo. Pasiones colectivas y afectos propios en la teoría social, Madrid, Alianza, 1993, pp. 49-64.

31. Vid. Subirats, Eduardo: "Razón y nihilismo", en Metamorfosis de la cultura moderna, Barcelona, Anthropos, 1991, pp. 17-35. Sánchez-Mejía, María Luisa: "Desencanto político y nostalgia del paraíso en los orígenes del 'mal du siècle", en Thélème: Revista complutense de estudios franceses, $n^{\circ} .9$ (1996), pp. 247-262. 
rar el camino trazado según una u otra interpretación.

A partir de Termidor, la nueva élite revolucionaria es consciente de que ha llegado la hora de sustituir aquel espíritu de derribo del primer momento revolucionario por el espíritu de construcción y conservación de los buenos frutos de la Revolución. Pero ¿cuáles son esos buenos frutos? Básicamente los principios que emergieron en 1789, que han de ser rescatados, restituidos y depurados respecto de los malos frutos de la experiencia jacobina del 93. Como llegará a decir Guizot, se trataba «de purger les principes de 1789 de tout alliage anarchique»32. Verbo ya utilizado por la Ideología: Cabanis abogaba por «la démocratie purgée de tous ses inconvéniens», derivados en esencia de la pretensión del pueblo —al que desdeñosamente califica de "classe ignorante»de influir en la tarea legislativa o en la de gobierno, afirmando que el objetivo es un sistema político donde: "Tout se fait pour le peuple et au nom du peuple; rien ne se fait par lui ni sous sa dictée irréfléchie»33.

32. Vid. Guizot, François: "Discours à la Chambre des députés du 14 mars 1838", en Histoire parlementaire de France, Recueil complet des discours prononcés dans les Chambres de 1819 à 1848 par M. Guizot, París, Michel Lévy Frères, t. III, 1863, p. 153. Rosanvallon, Pierre: Le moment Guizot, París, Gallimard, 1985, (trad. al castellano de Hernán M. Díaz, El momento Guizot. El liberalismo doctrinario entre la Restauración y la Revolución de 1848, Buenos Aires, Biblos, 2015, p. 221).

33. Cabanis, Pierre-Jean-Georges: Quelques considérations sur l'organisation sociale en général, et particulièrement sur la nouvelle Constitution, Commission du Conseil des Cinq-cents, París, Imprimerie Nationale, Frimario año VIII (1799), p. 27 (también puede seguirse la versión en castellano a cargo de Luis Risco, Algunas consideraciones acerca de la organización social en general, y en particular sobre la nueva Consti-
Reina en el ambiente un espíritu de desprecio y desquite ${ }^{34}$. Ha sobrevivido el despotismo, ahora en manos de los nuevos amos de la Ciudad del hombre.

Al liberalismo le llega la hora de conservar los logros obtenidos, de consolidar el nuevo sentido del poder, de edificar las nuevas instituciones. Cansados de soñar con abstracciones, aquella generación se enfrenta a la tarea que le imponen las circunstancias, no las ideas. Para esa aventura no sirven los usos políticos manejados; se necesitan otros modos que posibiliten la gran empresa de la estabilidad posrevolucionaria que pueda aunar el orden y la libertad. Pero, ¿cómo acometer la síntesis del proceso revolucionario?, ¿cómo conciliar la fe en el hombre y la fe en Dios, lo nuevo y lo eterno, después de lo vivido?, ¿qué se puede rescatar para empezar a construir? En palabras de Innerarity « ¿cómo es posible reconciliar al individuo particular con su comunidad política concreta y un orden cósmico general bajo las condiciones que ha producido la idea moderna de libertad?»35.

Hasta los gigantes de la filosofía de la época abordan esta preocupación. Tanto Kant como Hegel - que a diferencia de otros pensadores, aceptaron la inevitabilidad del Terror ${ }^{36}$ _ participan de esta toma de conciencia generacional en la que han

tución, en Sánchez-Mejía, María Luisa (ed.), Cabanis y Destutt de Tracy. Textos politicos de los Ideólogos, Madrid, Centro de Estudios Políticos y Constitucionales, 2004, p. 19).

34. Vid. Woronoff, Denis: La République Bourgeoise. De Thermidor à Brumaire, 1794-1799, París, Éditions du Seuil, 1972 (trad. al castellano de Javier Alfaya, La República Burguesa. De Termidor a Brumario 1794-1799, Barcelona, Ariel, 1981).

35. Innerarity, op. cit., p. 41.

36. Vid. Mayer, op. cit., pp. 116-117. 
comprobado cómo la libertad individual en un sentido radical colisiona con las demás libertades individuales, destruyendo los lazos sociales y la misma libertad.

Kant, especialmente a través de la obra Sobre la paz perpetua (Zum ewigen Frieden. Ein philosophischer Entwurf, Könisgberg, 1795), considera que la misión fundamental del poder civil es garantizar la convivencia social, esto es, que la libertad individual pueda coexistir con la libertad de los demás, apuntando la necesaria vinculación de la libertad con la moral. La universalidad de la moral supone la igualdad de todos los individuos en tanto sujetos morales, afirmándose, en cuanto personas racionales, su dignidad de la cual se deriva su libertad política. La política debe subordinarse a la moral, por lo que su finalidad no es la felicidad, sino la defensa y el respeto de los derechos inalienables de la persona, fundamento de todo orden político legítimo ${ }^{37}$. Kant contrapone el estado de naturaleza, donde los hombres actúan a su antojo, frente al estado civil, donde una ley superior marca el límite externo de la libertad individual. De este modo, si el estado de naturaleza se identifica con el Derecho privado, la sociedad civil lo hace con el Derecho público. El tránsito del estado de naturaleza a la sociedad civil se hace a través de la razón con el contrato originario por el que un pueblo se constituye en Estado y las voluntades particulares convergen en una voluntad general de conformidad con los principios de libertad, imperio de la ley e igualdad. Esto supone que el Estado civil descansará en tres pilares: la libertad

37. Vid. Touchard, Jean: Histoire des idées politiques, París, Presses universitaires, 1959 (trad. al castellano de J. Pradera, Historia de las ideas políticas, Barcelona, Círculo de Lectores, 1990, t. II, pp. 130 y ss.). Innerarity, op. cit., pp. 22; 48 y ss. en cuanto hombre (cada hombre puede obrar según su libertad individual siempre que no perjudique la libertad de otros), la igualdad civil en cuanto súbdito (es una libertad formal ante la ley, compatible con la desigualdad económica) y la autonomía en cuanto ciudadano (la cualidad de ciudadano procede de la propiedad; la autonomía supone no obedecer otra ley que aquella a la que los ciudadanos han otorgado su consentimiento) ${ }^{38}$.

Por su parte, Hegel, principalmente con la obra Rasgos fundamentales de la Filosofía del Derecho o compendio de Derecho natural y Ciencia del Estado (Grundlinien der Philosophie des Rechts oder Naturrecht und Staatswissenschaft im Grundrisse, Berlin, 1821), señala que la libertad individual necesita para realizarse el componente referencial de la libertad en sociedad. Para concretarse en la realidad, la razón debe relativizarse, despojarse de la abstracción: el hombre no es sólo un ser racional sino que es también un ser moral y social ${ }^{39}$. La gran pregunta es cómo

38. Vid. Kant, Immanuel: La paz perpetua, Madrid, Tecnos, trad. al castellano de Joaquín Abellán, $2^{\mathrm{a}}$ ed., 1989, pp. 15 y ss. Delgado Fernández, Santiago y Jiménez Díaz, José Francisco: “Introducción. Los antecedentes: Las ideas políticas de los ilustrados en el contexto europeo. 4.- Ilustración alemana: el pensamiento político de Immanuel Kant", en Delgado Fernández, Santiago y Jiménez Díaz, José Francisco (eds.): Introducción a la Historia de las Ideas politicas Contemporáneas, Granada, Universidad de Granada, 2008, pp. 31-35. Rosanvallon, Pierre: Le sacre du citoyen. Histoire du suffrage universel en France, París, Gallimard, 1992 (trad. al castellano de Ana García Bergua, La consagración del ciudadano. Historia del sufragio universal en Francia, México, Instituto Mora, 1999, pp. 101 y ss.). Díez del Corral, op. cit., pp. 226-229. Béjar, op. cit., pp. 65-87.

39. Vid. Innerarity, op. cit., pp. 23 y ss.; 48 y ss.; 66 y ss. También Touchard, op. cit., II, pp. 137 y ss. Díez del Corral, op. cit., pp. 229-232. 
relacionar las ideas de libertad y de autonomía moral del individuo con la inevitabilidad social; cómo la insalvable dimensión social obliga a relativizar los conceptos y a adaptar las ideas al nuevo tiempo de síntesis entre la emancipación individual y la ligazón social, permitiendo la realización de la libertad individual sin menoscabo de la libertad del otro. Por tanto, la libertad posible está indisolublemente ligada a unos referentes contextuales; así, para Innerarity:

«La libertad inhiere y se expresa en un contexto sociocultural, ninguno de cuyos elementos pueden considerarse aisladamente. [...] El conjunto de lazos y vínculos que resultan de este despliegue ya no es un argumento contra la realidad de la libertad; más bien ocurre lo contrario: el arraigo de la libertad en un espacio es su radical condición de posibilidad. El puro ideal de la razón debe tomar cuerpo en una forma sensible y en un entramado social, pero esto no supone una liquidación de la racionalidad, sino su realización cumplida ${ }^{40}$.

Hegel se opone a la tendencia del liberalismo a trasladar el núcleo de la vida social y política del Estado al individualismo del mercado, aduciendo que un individuo que persigue únicamente sus intereses egoístas no puede ser el eje de la políti$\mathrm{ca}^{41}$. Escribe Innerarity en este sentido que para Hegel:

40. Innerarity, op. cit., pp. 56-57.

41. Vid. Riezu Martínez, Jorge: "La teoría política de Hegel”, en Delgado Fernández y Jiménez Díaz, op. cit., pp. 86-87. Hegel, Georg Wilhelm Friedrich: Fundamentos de la Filosofia del Derecho o Compendio de Derecho Natural y Ciencia Politica, edición, traducción, estudio preliminar y notas de Joaquín Abellán, Madrid, Tecnos, 2017, pp. 200-202, §185; 260-262, §261.
«El tráfico mercantil es un ámbito éticamente neutralizado para la persecución estratégica de intereses privados, y por eso no puede ser un ámbito de integración [...] Es necesario subsumir los antagonismos en la esfera de una eticidad viva, precisamente en este momento en el que, frente al espejismo de una liberación individual, «las ideas morales pueden encontrar un sitio en el hombre», de tal modo que «las constituciones que solo garantizan la vida y la propiedad dejan de ser las mejores». Solamente puede superarse la paradoja de una libertad que termina creando un «aparato de terror» (der ängstliche Apparat) si la libertad se entiende como configuración de una comunidad política, si se abandona la atomización de subjetividades hostiles a favor de una solidaridad compatible con la libertad individual» ${ }^{42}$.

Según Hegel, el Estado es una realidad política fundamental en tanto «realización de la libertad concreta» ${ }^{43}$ : si el hombre puede ser libre, sólo podrá serlo dentro del Estado, en tanto «esfera de la conciliación de lo universal y lo particular» ${ }^{44}$. El Estado hegeliano se concibe como cúspide de la historia al posibilitar el desarrollo de la libertad, del derecho, de las costumbres, del arte, etc. Hegel señala la división del derecho, en cuanto «ámbito de la libertad realizada» ${ }^{45}$, en: derecho absoluto (propio de la voluntad individual inmediata), moralidad (que se manifiesta en la individualidad subjetiva) y eticidad (que se encuentra en la voluntad objetiva en relación con el mundo externo del hombre, es decir, de la familia, la sociedad y el Estado). La eticidad «es la razón que se hace consciente de sí en cuanto se ha realizado en las instituciones histórico-políticas de un pueblo y sobre todo de/ Estado», escri-

42. Innerarity, op. cit., p. 71.

43. Hegel, op. cit., pp. 259-260, §260.

44. Vid. Touchard, op. cit., II, p. 144.

45. Hegel, op. cit., p. 31, §4. 
be Riezu ${ }^{46}$. Ese despliegue de la eticidad culmina en el Estado, síntesis de la familia y de la sociedad civil. El Estado, a su vez, se despliega en tres momentos dialécticos: el derecho interno del Estado o Constitución, el derecho externo del Estado en relación con los demás, y finalmente, la historia del mundo. Hegel se postula a favor de la monarquía constitucional, renegando de la soberanía popular ${ }^{47}$ y concibiendo a la clase media como columna básica del Estado en cuanto en ella «se encuentra la conciencia jurídica y la inteligencia cultivada del conjunto de un pueblo» ${ }^{48}$. Frente al universalismo revolucionario, reconoce que «cada pueblo posee la Constitución que le corresponde y es adecuada a él $/ »^{49}$ y, aunque acepta la idea de división de poderes, sin embargo los subordina al poder del monarca en tanto encarnación real de la personalidad del Estado ${ }^{50}$.

La realización de la libertad requiere en consecuencia de los referentes sociales, culturales e históricos. Más allá del individualismo moral kantiano la eticidad hegeliana liga la libertad del individuo a la inevitable ética colectiva o razón universal; su libertad posible sólo puede existir dentro del Estado, las leyes y las instituciones. Frente a la universalidad de la libertad del 89, para la nueva libertad censitaria los resortes han devenido necesarios, son —calificativo legitimador de la época-útiles ${ }^{51}$.

46. Riezu Martínez, "La teoría política de Hegel", op. cit., p. 86.

47. Hegel, op. cit., pp. 288-292, §279.

48. Hegel, op. cit., p. 305, §297.

49. Hegel, op. cit., p. 285, §274.

50. Vid. Riezu Martínez, "La teoría política de Hegel”, op. cit., pp. 81-95.

51. Vid. Hegel, op. cit., pp. 147-148, §135. Sprute, Jürgen: Filosofia política de Kant, Madrid, Tecnos, 2008. López Calera, Nicolás María: El

\section{Anudando la cadena de los tiempos: la búsqueda de referentes}

A la libertad nacida de la Revolución hay que asociarle unos referentes de orden que hagan posible la convivencia social. Pero, ¿cuáles son esos referentes y dónde encontrarlos?

Los defensores de la libertad posible fijan sus miras en el modelo político británico; sin embargo transportarlo a Francia sería caer de nuevo en el error de la abstracción, en la política de laboratorio, tan ajena a la vida, a las sociedades, a los pueblos y a su historia. Los usos políticos se van a ir construyendo a golpe de necesidad; la nueva sociedad requiere una nueva convivencia política donde las diferencias puedan manifestarse dentro de un espacio de libertad posible que permita desarrollar el debate de ideas sin que por ello se desemboque en el peligro de la guerra civil entre los defensores del despotismo absoluto y los del despotismo de la libertad ${ }^{52}$. En este contexto, se esgrime la importancia de organizar un grupo de centro, equidistante entre extremos irreconciliables, cuya percepción abismática de la política les conducirá a la obsesión doctrinaria del justo medio; una vez despojados de la estrategia de oposición y arropados en la de gobierno a partir de 1830, sus delirios les conducirán a la bunkerización no ya frente a la política, sino frente a la realidad.

riesgo de Hegel sobre la libertad, Granada, Universidad de Granada, 1973.

52. Vid. Lario, Ángeles: "Monarquía Constitucional y Gobierno Parlamentario", en Revista de Estudios Políticos, n 106 (octubre-diciembre 1999), pp. 277-288. 
Si 1789 había sublimado la libertad, el individuo y la abstracción, a partir de 1795 cunde el recelo, retomándose el concepto de sociedad frente al de individuo, anhelándose la seguridad, el orden, la cristalización de los principios, la positivación de los derechos, la recuperación de los referentes que devuelvan las ideas y los principios al arraigo con la realidad, lo que lleva a sustituir el mito abstracto de la universalidad por la concreción nacional —los historiadores se afanarán desde entonces en mitificarla; necesitan una epopeya, pronto la encontrarán: Bonaparte- - El sujeto político toma conciencia de que, además de racional, es un sujeto social, moral e histórico. Es momento de aprendizaje de una nueva cultura política. Este proceso de relectura pretende construir una racionalidad política que permita fundar un orden público estable basado en los principios - revisados, purgados, depurados — del 8953. Siguiendo a Guizot:

«Nos esforzamos hoy, y con mucha razón, por unir lo que somos a lo que hemos sido antaño; sentimos la necesidad de enlazar los sentimientos con los hábitos, las instituciones con los recuerdos, de anudar en fin la cadena de los tiempos que no se deja nunca romper totalmente, por muy violentos que sean los golpes que se le apliquen» ${ }^{54}$.

Es la gran tarea pendiente. La Revolución ha enseñado que, traspasados ciertos límites, se lanza desbocada al precipicio de la disolución social, al abismo de la anarquía. Pero, ¿cuáles son esos límites?, ¿cuál es el nuevo espacio, el camino posible donde aunar orden y libertad? La retórica disimula mal una idea que la élite burguesa ha inte-

53. Vid. Rosanvallon, El momento Guizot, op.cit., pp. 12-13.

54. Guizot, Historia de los orígenes del gobierno representativo en Europa, op. cit., p. 47 (resaltado en el original). riorizado: «La Revolución ha sobrepasado sus objetivos al haber atacado la propiedad en nombre de la igualdad y al haber atentado contra la libertad en nombre de la soberanía popular» ${ }^{55}$.

El espejismo de la liberación individual ha hecho tambalear a las antiguas jerarquías, porque el hombre ha acusado a los inveterados referentes de la autoridad como causantes de su desgracia. Esa individualidad, por otra parte, es señalada por su atomización, por su anarquismo, por su peligro disgregador, incompatible con aquella titánica tarea de reconstrucción social ${ }^{56}$. En la política alborearán las estrategias de nuevos paraísos prometidos (ya de ayeres míticos, ya de futuros utópicos), espejismos que ahondarán en la insatisfacción del hombre moderno, Sísifo contemporáneo. Así, siguiendo a Innerarity:

«Futurismo revolucionario y tradicionalismo son las dos patologías que surgen con la pérdida del sentido de lo contemporáneo. La tesis de Hegel es que la realidad de una existencia histórica desgarrada no puede ser reconducida a la unidad por una racionalidad abstracta. Cuando lo unilateral -ya sea el sujeto o el objeto aislado, el futuro o el pasado, la emancipación o el orden se concibe como absoluto, el intento de realizar la unidad sólo puede tener la forma de una constricción. A esto se debe el que tanto el progresismo revolucionario como el tradicionalismo restauracionista adopten necesariamente una praxis política autoritaria. Ninguno de ambos está en condiciones de configurar un entramado político que asegure lo que gracias a la revolución ha entrado en la historia» ${ }^{57}$.

55. Sánchez-Mejía, Benjamín Constant y la construcción del liberalismo posrevolucionario, op. cit., p. 95.

56. Vid. Innerarity, op. cit., pp. 71-72.

57. Innerarity, op. cit., p. 172. 
En este mismo sentido escribe Guizot:

«El pasado tan despreciado, tan abandonado por unos, se ha convertido para otros en el objeto de un culto idolátrico. Aquéllos querían que la sociedad, mutilándose a sí misma, abjurase de su vida anterior; éstos le piden que retorne a sus orígenes para permanecer allí inmóvil e impotente. Y así como los primeros, dueños del futuro, creaban entonces a su antojo las más brillantes utopías en materia de gobierno y de orden social, los segundos sueñan a su vez con utopías del pasado»58.

Sin embargo en lontananza no se advierten paraísos; al contrario: "La acción que surge de esta ruptura es el fanatismo, la destrucción de lo concreto en nombre de una abstracción. La libertad abstracta es desolación y violencia contenida» ${ }^{59}$. Ante lo cual, « [...] el esfuerzo romántico por reconciliar la política con la religión condujo al escepticismo romántico con respecto a las panaceas constituidas por reformas políticas puramente organizativas» ${ }^{60}$.

La contingencia de la realidad desborda a las pretensiones geométricas de la razón. El hombre nuevo que ha traído la contemporaneidad ha descubierto que la infalibilidad de la razón, azote de dogmas, pilar de la nueva era, ha resultado ser también un dogma; no lo reconocerá, y volverá a intentar encajar la realidad en sus proyectos abstractos, obteniendo, ante su insatisfacción, el mismo resultado: crueldad, nihilismo, barbarie.

La clave del momento es asegurar lo que gracias a la Revolución ha entrado en la

58. Guizot, Historia de los orígenes del gobierno representativo en Europa, op. cit., p. 54.

59. Innerarity, op. cit., pp. 172-173.

60. Schenk, op. cit., p. 56.
Historia, buscando fórmulas capaces de hacer arraigar el nuevo espíritu del siglo sobre el legado de los tiempos. Sin embargo, ante esta tarea, la angustia de la razón provoca el anhelo del mito:

« [...] la sociedad burguesa parece haber entrado en un proceso de descomposición, ya que desde la noción de individuo es imposible pensar lo común. [...] el romanticismo alemán es el primer acontecimiento cultural de la era moderna que tematizó el problema de la identidad en un medio social de alienación. La nostalgia por el mito surge desde esta preocupación» ${ }^{61}$.

En contraste, la política reducida a la gestión de la realidad, tal y como exigía la fuerza de los hechos, está por hacer, y a la larga aburre, como Lamartine llegará a acusar a Guizot cuando aún no había saltado por los aires la Monarquía de Julio: "La France est une nation qui s'ennuie!». El desengaño que produce la quiebra de la confianza en las luces es silenciado con las glorias del Imperio; pero en 1814 ha llegado la hora de templar ese caballo desbocado sobre el que ha cabalgado una Francia nueva y en aquellos momentos exhausta. Se pretende encontrar la estabilidad política y social, pero a poco que se vuelve la vista atrás se contemplan unos años irrepetibles, de una intensidad desconocida: nace la epopeya en torno a la Revolución y el Imperio. Tras las agitaciones de los años treinta, el spleen irá impregnando unos espíritus en los que brotarán, a mediados de siglo, las flores del mal. Por su lado, el arte, que intuye el agotamiento del discurso romántico, tratará de huir del retrato de la realidad que impone el academicismo. Mientras tanto, por debajo de aquel tedio burgués, tal vez

61. Innerarity, op. cit., p. 47. 
cierto, tal vez impostado, fluye el magma del infierno que padece el proletariado industrial; en el ocaso del siglo habrá generaciones que anhelen la destrucción total, los privilegiados por aburrimiento, los desheredados por necesidad ${ }^{62}$.

\section{La reinvención posrevolucionaria del liberalismo francés}

La conexión del Terror con la idea de la absolutización de la libertad es el argumento esencial sobre el que se va a asentar la estrategia política de los defensores de su limitación. La cuestión

62. Vid. Rosanvallon, El momento Guizot, op. cit., pp. 249 y ss. Ponteil, op. cit., pp. 22 y ss. Droz, op. cit., pp. 103-136. Díez del Corral, op. cit, pp. 51 y ss.; 429-454. Craiutu, Aurelian: Liberalism under Siege: The Political Thought of the French Doctrinaires, Lanham, Maryland, Lexington Books, 2003 (trad. al francés de Isabelle Hausser : Le Centre introuvable. La pensée politique des doctrinaires sous la Restauration, París, Plon, 2006, pp. 41 y ss.). Maurois, André: Histoire de la France, París, Wapler, 1947 (trad. al castellano de María Luz Morales, Historia de Francia, Barcelona, Círculo de Lectores, 1973, pp. 403 y ss.). Steiner, George: In Bluebeard's Castle: Some notes towards the redefinition of culture, New Haven, Yale University Press, 1971 (trad. al castellano de Alberto L. Budo, En el castillo de Barba Azul. Aproximación a un nuevo concepto de cultura, Barcelona, GEDISA, $2^{\mathrm{a}}$ ed., 1992 [1 ${ }^{a}$ ed. en 1991], pp. 32 y ss.). Lesmes, Daniel: Aburrimiento y capitalismo. En la escena revolucionaria: París, 1830-1848, Madrid, PreTextos, 2018. Las palabras de Lamartine en Mavida, M.J. ; Laurent, M.L. (fond.) ; Barbier, G. ; Claveau, L. ; Lataste, L. ; Pionnier, C. (dir.) : Archives parlementaires de 1787 à 1860, Recueil complet des débats législatifs et politiques des Chambres françaises, Deuxième série (1800 à 1860), t. CXXIII, París, Dupont, 1911, sesión de 10 de enero de 1839 , pp. 161 y ss. era repensar una nueva forma de libertad que no se precipitara a la disolución social y a su propia destrucción. Los únicos caminos posibles de realización de la libertad reclamaban el abandono de la pureza idealista en favor de la practicidad $^{63}$. Retomando a Innerarity:

"La necesidad que había sido expulsada por la puerta de la metafísica, entra — con todos los honores - por la ventana de la filosofía de la historia. Efectivamente, un destino gobierna la historia, pero no es un destino ciego, sino providente. Nunca la historia se había cargado de tanta esperanza como cuando se la declaró obra exclusiva del hombre» 64 .

Retorna la historia por las grietas de la razón. Para una burguesía que había alcanzado el poder, la herencia iusnaturalista que había alimentado sus esperanzas durante el siglo XVIII deviene incómoda, inútil ya para sus intereses de clase. Había que despojar en consecuencia al liberalismo, en tanto ideología de la nueva élite, de todo componente desestabilizante y revolucionario que pusiera en peligro el nuevo statu quo, renegando del que había sido su referente: Rousseau ${ }^{65}$. En su anhelo de estabilidad, el liberalismo dejaba de ser revolucionario para aprender a ser conservador: los nuevos pilares necesitan reforzarse, no cuestionarse. Escribe Sánchez-Mejía:

"Los caminos de la utopía son ya caminos explorados y ya se sabe a dónde conducen. La inocencia del 89 y del 93 ha desaparecido;

63. Vid. Innerarity, op. cit., pp. 169 y ss.

64. Innerarity, op. cit., p. 118.

65. Rosanvallon, El momento Guizot, op. cit., p. 36. Vid. Varela Suanzes-Carpegna, Joaquín: "El liberalismo francés después de Napoleón (De la Anglofobia a la Anglofilia)", en Revista de Estudios Políticos, no 76 (abril-junio 1992), pp. 29-43. 
[...] la revolución ha envejecido y ha llegado el momento de hacer balance y sacar las consecuencias de las lecciones aprendidas en la cruda realidad ${ }^{66}$.

Pero la tempestad del Terror había barrido las referencias. En esta tierra baldía no hay política diseñada, todo estaba por hacer: el vacío ha sido radical. La orfandad de esta generación le hace madurar. En medio del desconcierto termidorianodirectorial, se impone el pragmatismo. La nueva política se va haciendo poco a poco: Francia vive instalada en la urgencia y no hay tiempo para teorías, sino para gobernar, porque los peligros son demasiado poderosos como para retirarse al análisis y al estudio. Si entonces dominaba la abstracción, ahora mandan las circunstancias ${ }^{67}$. Y ahí, sobreviviendo entre dos límites poderosos, entre dos simas profundas -el Antiguo Régimen y la Revolución - va abriéndose camino un liberalismo nuevo, que está extrayendo las lecciones que el devenir de la Revolución ha impartido. Había que esgrimir un liberalismo equidistante tanto de las fuerzas de la reacción absolutista, como del liberalismo revolucionario; un espacio de justo medio entre el despotismo absoluto y el despotismo de la libertad. La síntesis de estas dos herencias irrenunciables la de la revolución y la de la historia, la de la libertad y la del orden- es el objetivo que se marca una tercera vía obsesionada por establecer un régimen político libre y sólido, mediante una política racional que garantice el gran anhelo de la estabilidad, contemplando el modelo inglés como

66. Sánchez-Mejía, Benjamín Constant y la construcción del liberalismo posrevolucionario, op. cit., p. 67.

67. Vid. Sánchez-Mejía, Benjamín Constant y la construcción del liberalismo posrevolucionario, op. cit., pp. 64 y ss. ejemplo de equilibrio práctico entre la libertad y el orden. Está naciendo el liberalismo posrevolucionario.

El nuevo liberalismo reconoce algunos valores revolucionarios de los que no está dispuesto a desligarse (la libertad, la propiedad), pero ahora se reclama conservador: para legitimarse contempla con respeto a la Historia, como didáctica no condicionante, y al Estado-nación como contexto de identidad, y reniega de la tabla rasa revolucionaria, del mito del momento cero y de la propia idea de universalidad, conceptos tributarios de un programa que ha resultado imposible. En el reajuste receloso de la élite, comienza el repliegue hacia la identidad. Aspirará a un modelo político donde para sobrevivir a los abismos tengan que colaborar la historia y la Revolución, el rey y el Parlamento, el orden y la libertad. En este contexto dialéctico nace, con espíritu de síntesis, el liberalismo posrevolucionario: «El sendero de la libertad es sumamente estrecho: a un lado y a otro amenazan los terribles precipicios del despotismo y la anarquía, que tienen entre sí una comunicación oculta» ${ }^{68}$. Se instala una idea que cala: "La anarquía es la tiranía de todos, así como el despotismo es la tiranía de uno solo» 69 .

Se abren los dos grandes procesos de positivación: el constitucionalismo para

68. Lista, Alberto: "Constitution de la nation française, avec un essai de traité et un recueil de pièces correlatives; par le comte Lanjuinais, pair de France, membre de 1'Institut, etc. 1819', en El Censor, t. I, nº 2 (12 de agosto de 1820), pp. 112-113.

69. Lista, Alberto: "Continúa el discurso anterior", en El Espectador Sevillano, n ${ }^{\circ} .50$ (20 de noviembre de 1809), p. 199. 
el Derecho público y la codificación para el Derecho privado ${ }^{70}$. Hay que consolidar el poder constituido: frente a los ideales, se imponen las instituciones, llegándose a afirmar que «El bien debe esperarse de las instituciones, no de los individuos ${ }^{71}$. Del mismo tenor, Hegel, para quien las instituciones del Estado «forman la racionalidad desarrollada y realizada» escribe: "Las instituciones son los pilares de la libertad pública, ya que en ellas la libertad particular es racional y está realizada ${ }^{72}$. Durante Termidor y el Directorio los dos referentes intelectuales más poderosos son Sieyès y Burke. El primero traslada el miedo a la representación a sus reflexiones constitucionales, con importantes restricciones en el sufragio, la división del Legislativo y el refuerzo del Ejecutivo. Burke, por su parte, denuncia la idea de que la libertad sea el fruto universal de la abstracción; defendiendo, por el contrario, que la forma política y el derecho de una sociedad son producto de la historia de cada pueblo, son la expresión normativa de una sociedad y no de un ejercicio teórico de abstracción. En esa tarea de relectura se irá desarrollando el nuevo liberalismo. Si el liberalismo revolucionario pivota sobre el individuo, el liberalismo posrevolucionario descansa sobre la sociedad constituida. Consecuente-

70. Vid. Peces-Barba, Gregorio y Dorado Porras, Javier: "Derecho, Sociedad y Cultura en el siglo XVIII", en Peces-Barba Martínez, Gregorio; Fernández García, Eusebio; y De Asís Roig, Rafael (dir.): Historia de los Derechos fundamentales, $t$. II: siglo XVIII, Vol. I: El contexto social y cultural de los derechos. Los rasgos generales de evolución, Madrid, Dykinson-Instituto de Derechos Humanos Bartolomé de las Casas-Universidad Carlos III, 2001, op. cit., p. 126.

71. Lista, Alberto: "De la dictadura", en El Censor, t. XI, núm. 62 (6 de octubre de 1821), p. 104.

72. Hegel, op. cit., p. 264, §265. mente, si el concepto de "individuo" tiene una naturaleza dinámica, la del término "institución" es estática; el primero evoca la acción del poder constituyente, mientras que el segundo, la estabilidad del poder constituido ${ }^{73}$.

$$
\star * \star
$$

Ante la imposibilidad de la solución monárquico-constitucional, a la moderación termidoriana sólo le quedará la República. Comienza a despuntar una nueva generación de republicanos moderados que constituyen una especie de intelligentsia, donde descuellan el grupo de los Ideólogos, Benjamín Constant y Madame de Staël. Sin embargo, el triunfo electoral de los monárquicos en septiembre de 1797, obliga al Directorio a pedir ayuda al ejército: no están dispuestos a ver morir la Revolución en manos del enemigo. Al recurrir al Ejército, el Directorio hipoteca su existencia a la voluntad del sable. Constant y Madame de Staël también aceptan la irremediable dictadura de las instituciones para evitar la de las persecuciones $^{74}$. A golpe de Brumario la libertad queda secuestrada. Ante esta situación, hay personajes que deciden colaborar (Sieyès, segundo cónsul y artífice de la Constitución del año VIII) y otros que se oponen: unos gradualmente desde dentro (los Ideólogos) y otros, tajantes, des-

73. Vid. p. ej. Sánchez-Mejía, María Luisa: "Repúblicas monárquicas y Monarquías republicanas. Las reflexiones de Sieyès, Necker y Constant sobre las formas de gobierno", en Revista de Estudios Políticos, no 120 (abril-junio 2003), pp. 195-217. Lario, Ángeles: "La Corona en el Estado liberal. Monarquía y Constitución en la España del siglo XIX”, en Historia Contemporánea, no. 17 (1998), pp. 139-157.

74. Vid. Sánchez-Mejía, Benjamín Constant y la construcción del liberalismo posrevolucionario, op. cit., p. 82. Woronoff, op. cit., pp. 201 y ss. 
de el exilio (Coppet: Madame de Staël y Constant) ${ }^{75}$.

Con la afirmación de Benjamin Constant de que la propiedad y los talentos retomaban sus derechos, se estaban admitiendo formas legítimas de desigualdad ${ }^{76}$. No es un apunte baladí; el nuevo liberalismo va a contar entre otros, con esos dos pilares fundamentales: la propiedad como nuevo criterio de estratificación social post-estamental y la soberanía de la razón como legitimador de la ciudadanía política. A estos pilares le acompañan dos vectores esenciales, la limitación del poder y los derechos del hombre 77 , premisas incompatibles con la dictadura de Napoleón. En el seno de la oposición al despotismo de Bonaparte surgen dos interpretaciones del liberalismo posrevolucionario: en Coppet se piensa en un liberalismo de individuo que incida en los derechos individuales frente al Estado, de fuerte protagonismo de la sociedad civil, cercano al modelo inglés, cosmopolita a la par que abierto a la

75. Vid. Takeda, Chinatsu: "Deux origines du courant libéral en France", en Revue Française d'Histoire des Idées Politiques, 2003 (2 ${ }^{\circ}$ semestre), $n^{\circ}$. 18: Les Ideólogues et le Groupe de Coppet, pp. 246 y ss. Bacot, Guillaume: "Les Idèologues et le groupe de Coppet", en Revue Française d'Histoire des Idées Politiques, 2003 ( $2^{\circ}$ semestre), $\mathrm{n}^{\mathrm{o}}$. 18: Les Ideólogues et le Groupe de Coppet, pp. 227 y ss. Sánchez-Mejía, María Luisa: "Madame de Staël y la Constitución del año III: el nacimiento del republicanismo liberal", en Historia Constitucional, $\mathrm{n}^{\circ} .16$ (2015), pp. 47-66.

76. Vid. Constant, Benjamin: "Carta a su tía Mme. de Nassau, de 29 de mayo de 1795 (10 de Pradial año III)", en Melegari, Dora (ed.), Journal intime de Benjamin Constant et lettres à sa famille et à ses amis, París, Albin Michel, 1928, p. 268 [1 $1^{\mathrm{a}}$. ed., París, Ollendorff, 1895, pp. 234-235], apud Sánchez-Mejía, Benjamín Constant y la construcción del liberalismo posrevolucionario, op. cit., p. 64. Díez del Corral, op. cit., pp. 140-144.

77. Vid. Craiutu, op. cit., p. 265. sensibilidad romántica; desde Francia se diseña un liberalismo de gobierno sobre la idea de reforzar al Estado para posibilitar la libertad del individuo, constituyéndose en un liberalismo estatalista, institucional, predominantemente político y sociológico en detrimento de lo económico, abierto al sentido común y cerrado a las abstracciones teóricas, receloso de la sociedad civil y de carácter paternalista y elitista. Se va configurando de este modo un liberalismo desde arriba, dirigido, anti-individualista, al que Rosanvallon denomina «libéralisme octroyé», y que será desarrollado durante la Restauración por el grupo doctrinario ${ }^{78}$.

78. Vid. Takeda, op. cit., pp. 235 y ss. Touchard, op. cit., II, pp. 166-167. Sánchez-Mejía, María Luisa: "La teoría política de los Ideólogos", en Sánchez-Mejía, Textos políticos de los Ideólogos, op cit., pp. XI-XXII. Díez del Corral, op. cit, pp. 32 y ss. Craiutu, op. cit., passim. Jaume, Lucien: L'individu effacé ou le paradoxe du libéralisme français, París, Fayard, 1997, pp. 25-169. Jaume, Lucien: "Le libéralisme français après la Révolution, compare au libéralisme anglais", en Historia Constitucional, no. 4 (2003), pp. 383-393. Girard, Louis : Les libéraux français, 1814-1875, París, Aubier, 1985, pp. 5-47. Rosanvallon, Pierre: La Monarchie impossible. Les Chartes de 1814 et de 1830, París, Fayard, 1994, pp. 45 y ss. Rosanvallon, Pierre : Le modèle politique français. La société civile contre le jacobinisme de 1789 à nos jours, París, Ed. du Seuil, 2004 (trad. al castellano de Víctor A. Goldstein, El modelo politico francés : la sociedad civil contra el jacobinismo, de 1789 a nuestros días, Buenos Aires, Siglo XXI, 2007, pp. 71 y ss.), Lacchè, Luigi: La Libertà che guida il Popolo. Le Tre Gloriose Giornate del luglio 1830 e le "Chartes» nel costituzionalismo francese, Bolonia, Il Mulino, 2002, pp. 21 y ss. Cassese, Sabino: Il diritto amministrativo: storia e prospettive, Milán, Giuffrè Editore, 2010 (trad. al castellano: Derecho Administrativo: Historia y futuro, Madrid, Instituto Nacional de Administración Pública-Editorial Derecho Global, 2014 especialmente "Capítulo Primero: La construcción del Derecho Adminis- 


\section{A modo de conclusión}

Pero, ¿no era el ejemplo inglés el modelo a seguir?

Para aquel propósito de adaptación podrá servir de ejemplo, pero no de dictado a una Francia escudada en su papel geopolítico e histórico. Francia, que antepone la gobernabilidad a la libertad individual — a la que achaca su tendencia a la atomización de los intereses, a la disolución social-, prefiere centrar su atención en el equilibrio institucional británico pues considera una simpleza reducir el ejemplo inglés a un liberalismo de individuo cuando en realidad por encima del individuo inglés, antes del individuo inglés, existen sus instituciones, esos poderosos pilares de la vida inglesa. Desconcertante paradoja.

Surgen las disonancias: las instituciones inglesas descansan en la capacidad legitimadora de la historia; los franceses, en cambio, han cultivado la razón con tal profundidad que ha dejado una huella característica, una identidad propia: ¿cómo van a regirse de nuevo por la oscuridad de la costumbre, expresión normativa de la historia, si han aspirado a la idealización de la seguridad exacta de la Ley, expresión normativa de la razón? Es una vuelta atrás sin sentido ${ }^{79}$. Otro detalle: gracias en

trativo: Francia y Reino Unido", trad. Alberto Montaña y Manuel Martínez Neira, pp. 37 y ss.).

79. Vid. Jaume, Lucien: "Le libéralisme français après la Révolution, compare au libéralisme anglais", en Historia Constitucional, $n^{\circ} .4$ (2003), pp. 383-393. Lucien Jaume distingue dos tendencias fundamentales en el liberalismo: una, que se rige por el orden espontáneo en la economía de mercado, en la moral, en el papel de las jerarquías sociales (tendencia que se encuentra en la escuela inglesa y sobre todo escocesa); y otra que hace cerrado elogio de la ley como principio de acción (tendencia francesa). Estas dos tendencias gran parte a un entramado institucional inclusivo (la Corona, la nobleza, el pueblo) y a un eficaz sistema de equilibrios, Inglaterra no padece aquel riesgo permanente de guerra civil — política y, sobre todo, social- tan latente en Francia a lo largo del siglo XIX. Surge otra diferencia de calado: la tradición política inglesa descansa en la centralidad de la Supreme Court, de

descansan en las fuerzas sociales que entran en escena, con una aristocracia inglesa implicada directamente en el funcionamiento institucional del reino y colaborador en el mantenimiento del vínculo sociedad/Estado (lógica del compromiso), mientras que en Francia el Estado se construye desde la ley y frente a los enemigos del constitucionalismo, como entre otros la aristocracia (lógica de la ruptura); vid. Jaume, Lucien: "El liberalismo posrevolucionario: Francia e Inglaterra", en Robledo, Ricardo; Castells, Irene; Romeo, $\mathrm{M}^{\mathrm{a}}$ Cruz (eds.): Orígenes del Liberalismo. Universidad, Política, Economía, Salamanca, Universidad de Salamanca-Junta de Castilla y León, 2003, pp. 144 y ss. Por su parte, Rosanvallon señala cómo el legicentrismo a la francesa implica que el reinado de la ley no concluía en la noción de Estado de Derecho, sino que expresa un ideal de racionalización política y social. El racionalismo político a la francesa reposa en la certeza de que el interés general no es, como en el modelo inglés, el simple compuesto de los intereses particulares, sino que "participa esencialmente de una simbología de la pertenencia social y de una forma de apropiación colectiva del antiguo poder real", de tal manera que al confundir el sufragio universal con el gobierno de la multitud, la evolución histórica del parlamentarismo en Francia es brutal e irregular, frente al carácter progresivo y regular de la ampliación del sufragio en Inglaterra, vid. Rosanvallon, La consagración del ciudadano..., op. cit., pp. 137 y ss., 416 y ss. Siedentop, Larry: "Two Liberal Traditions", en Alan Ryan (ed.), The Idea of Freedom, Oxford, Oxford University Press, 1979, pp. 153-174. Craiutu, op. cit., pp. 263 y ss. Varela Suanzes-Carpegna, "El liberalismo francés después de Napoleón (de la anglofobia a la anglofilia)", op. cit., pp. 29-43. Cassese habla de "las dos vías del estado moderno en Occidente" vid. Cassese, op. cit. pp. 27 y ss. 
ahí la fortaleza de su sociedad civil (libertad inherente que se defiende -libertad per se_) en la que el individuo no queda difuminado en la representación; por el contrario, en Francia, como en el resto del continente, el monarca había acaparado todo el poder, generando la ruptura revolucionaria y la permanente idea de garantizar la libertad frente al rey (libertad ausente que se reclama - libertad frente a-, libertad ausente que se concede — libertad gracias a-). Esto asienta la idea de que la libertad no se despliega desde el individuo hacia el poder, sino a la inversa, lo que unido al recelo hacia la representación —no solo se trata de una desconfianza hacia el individuo en sí, sino incluso hacia el individuo representado: es el miedo al número en tanto desafío a la estratificación social, es el miedo a la democracia - con que se construye el liberalismo posrevolucionario continental, provoca el predominio del Ejecutivo en detrimento del Legislativo. Se fija así la idea del poder desde arriba. En consecuencia, la adaptación resulta ilusoria desde el recelo a la inherente libertad del individuo. El resultado de esta actitud de las élites francesas es la imposibilidad de adoptar una cultura de la libertad individual: les resulta más cómodo adaptar al nuevo tiempo el principio de autoridad ${ }^{80}$.

Son contextos y culturas políticas diferentes: en Gran Bretaña el liberalismo es conservador de un régimen político, de un equilibrio institucional y de unos modos de hacer política, así como de una sociedad civil estable, poderosa y acostumbrada a fiscalizar al poder; en una Francia que anhela esa estabilidad inglesa, todo está por

80. Según Lacchè, se trataba de «tutelare le libertà dell'individuo attraverso un'efficace organizzazione dei poteri dello Stato», vid. Lacchè, La Libertà che guida il Popolo, op. cit., p. 27. construir, por reforzar; incluso algunos fundamentos políticos quedan por definir (por ejemplo, el gobierno parlamentario, la responsabilidad ministerial, el poder neutro del rey): es una etapa de aprendizaje del gobierno parlamentario, de un liberalismo que está aprendiendo a ser conservador. Los nuevos tiempos imponen aunar la historia de Francia y la razón de los franceses. Además, Francia, temerosa de la capacidad política, social y económica de la libertad del individuo, anhela recomponer los lazos comunitarios en aras del imperativo de la gobernabilidad, argumentando que no ha experimentado veinticinco años de vértigo para convertirse en una mera sociedad de tenderos: el espíritu de grandeur es algo más que una bolsa de monedas y el ejemplo inglés demasiado mezquino para construir y exportar civilisation ${ }^{81}$. En esa actitud caben la mística del Imperio, la libertad guiando al pueblo y una Francia que a mediados de siglo pide sufragio universal cansada de aquella monarquía convertida en «una sociedad por acciones para la explotación de la riqueza nacional» por parte de la aristocracia financiera (una aristocracia de tenderos) ${ }^{82}$ — no solo es una criba censitaria a la libertad o a la representa-

81. Vid. Rosanvallon, El modelo politico francés, op. cit., pp. 96-104; 114 y ss.; 127 y ss. SánchezMejía, Benjamín Constant y la construcción del liberalismo posrevolucionario, op. cit., pp. 212213. Lacchè, Luigi: "Constitución, monarquía, parlamento: Francia y Bélgica ante los problemas y modelos del constitucionalismo europeo (1814-1848)", en Fundamentos, $\mathrm{n}^{\circ} .2$ (2000), pp. 467-543. Sólo el grupo de Coppet estaba convencido de que el ejemplo inglés era el modelo a seguir: en el resto de publicistas y políticos franceses reinaba el escepticismo, vid. Laquièze, op. cit., pp. 40 y ss.

82. Marx, Karl: Las luchas de clases en Francia de 1848 a 1850, Madrid, trad. A. S. Cuper, Austral, $2^{\text {a }}$ ed., 1992, p. 90. 
ción, también lo es al mercado_- la lenta consolidación de las instituciones por el contrario aburre a su espíritu inquieto.

Por eso el modelo que se impone tanto con Napoleón como con Luis XVIII —el rey que puede «absorber la Révolution dans la Monarchie»83 _ es que las élites, en su recelo hacia la representación, están dispuestas a acogerse a la tutela política de turno. Desde esa premisa se irá materializando, poco a poco el gobierno representativo en Francia. La transición del paternalismo de la voluntad del despotismo, al paternalismo de la razón de los notables encuentra en el doctrinarismo a sus teóricos. El grupo doctrinario, elitista, reducido, altivo, ejemplifica la estrategia política del gran burgués: intentará movilizar desde sus tribunas a la población para, una vez obtenido el triunfo, clausurar la revolución, escamoteándola en aras del orden como base fundamental de la estabilidad social y retomando su retórica de la propiedad y los talentos para blindar a los capaces. Sin embargo, el fiel de la balanza se inclinará a favor de la propiedad frente a los talentos (al fin y al cabo, éstos, siempre y cuanto no sean talentos para los negocios, pueden llegar a cuestionar esta concepción del mundo reducida a la obtención del beneficio económico como único mecanismo de prestigio social). La búsqueda incesante de la unidad social por parte de los doctrinarios evidencia su rechazo a la pluralidad inherente a la individualidad que ha irrumpido desde la Revolución ${ }^{84}$. Guizot —que aunque se

83. Vid. Lacchè, Luigi: "Las Cartas Otorgadas. La teoría de l'octroi y las experiencias constitucionales en la Europa post-revolucionaria", en Fundamentos, no .6 (2010), pp. 269-305 (la cita en p. 276). Díez del Corral, op. cit., pp. 51 y ss.

84. Rosanvallon, Pierre: "Les Doctrinaires sontils des libéraux?”, en Darío Roldán (ed.), Guizot, había labrado fama de ser el más anglófilo de los franceses, en el fondo resultó ser el más francés de los anglófilos - se alzará contra la concepción individualista-liberal según la cual el individuo es una creación moderna, calificándola de barbarie ${ }^{85}$. La libertad había sido un reclamo; el objetivo era la gobernabilidad.

Los valores humanistas que nutrieron al liberalismo quedaban cautelosamente silenciados, aunque dispuestos a ser cimbreados para volver a imponer periódicamente la revolución como método de conquista de sus intereses de clase. Al fin y al cabo, los notables han asimilado una ecuación: cuando Francia reposa, tiende al elitismo; cuando despierta, tiende a la revolución. Los teóricos de la política, particularmente los doctrinarios, silencian la economía; pero la economía, en silencio, maneja la política _-Ingres lo captó en las manos como garras de Louis-François Bertin (1832): retrataba las manos del poder ${ }^{86}$ _. Obsesionada con la acumulación de capital como vector existencial, la notabilidad burguesa presenta un modelo social carente de mística, de gloria, de romanticismo. De esta aristocracia de tenderos no puede brotar un arte vivo: si antes de 1830 domina la república de las letras una pléyade de escritores afectados de nostalgias, a partir de entonces la nueva generación transmuta el romanticis-

les Doctrinaires et la presse (1820-1830), ValRicher, Fondation François Guizot-Val Richer, 1994, pp. 133-139. Díez del Corral, op. cit., pp. 93 y ss.

85. Vid. Rosanvallon, El momento Guizot, op. cit., p. 50.

86. Rosanvallon, El momento Guizot, op. cit., pp. 211 y ss. Craiutu, op. cit., pp. 270 y ss. Vid. García Guatas, Manuel: Jean Auguste Dominique Ingres, Madrid, Historia16, El arte y sus creadores, $n^{\circ} .32,1993$, pp. 140-141. 
mo en revolucionario al reclamar libertad frente a una burguesía que, alcanzado el poder, había secuestrado el tiempo y los espíritus $^{87}$. Sin el recurso revolucionario, la élite burguesa irá descubriendo a medida que avanza el siglo la capacidad instrumental de una nueva estrategia de movilización: el nacionalismo. El terreno espiritual estaba abonado: todos ansían ligazones comunitarias útiles en el nuevo contexto de la modernidad, fijándose en la Historia y en la Nación, tiempo y lugar como anclajes sobre los que construir la libertad posible.

1830 desplazará también a los viejos ilustrados; su sueño de una base moral que sustente a la sociedad había caducado ${ }^{88}$ : comparten con los nuevos gobernantes el recelo hacia la libertad de todos, pero en el repliegue el propietario ha vencido al ciudadano. Las nostalgias siempre están condenadas por el tiempo. Blindado el presente, los nuevos privilegiados se reclaman dueños de su libertad y pondrán los mecanismos del nuevo Estado a su servicio para aplastar a todo el que pretenda desestabilizar su conquista política. Para María Zambrano, el drama del liberalismo, desde sus inicios, es que para ajustar la libertad a la realidad, la limitaron hasta negarla ${ }^{89}$, reduciéndola a la única libertad posible: la libertad de unos capaces que dormían sobre un volcán ignorando la advertencia de Tocqueville: « [...] la causa real, la causa eficiente que hace que los hombres pierdan el poder es que

87. Vid. Bénichou, La coronación del escritor, op. cit., pp. 254 y ss. Schenk, op. cit., p. 70. Touchard, op. cit., II, pp. 159-163.

88. Vid. p.ej. para Lista, Martínez Torrón, Diego: El alba del romanticismo español, Sevilla, AlfarUniversidad de Córdoba, 1993, pp. 342-343.

89. Vid. Zambrano, op. cit., pp. 232-233. se han hecho indignos de ejercerlo ${ }^{90}$. Ese alma humanista del liberalismo yacerá en el olvido y, a la larga, el proceso de deshumanización desembocará en la barbarie como industria ${ }^{91}$.

\section{Bibliografía}

Álvarez Tardío, Manuel: "Dieu et liberté: la alternativa del catolicismo liberal en el ochocientos", en Historia y Política, nº 3 (2000), pp. 7-30.

Bacot, Guillaume: "Les Idèologues et le groupe de Coppet", en Revue Française d'Histoire des Idées Politiques, 2003 (2 semestre), $n^{\circ}$. 18: Les Ideólogues et le Groupe de Coppet, pp. 227-231.

Bauman, Zygmunt: Modernity and the Holocaust, Ithaca, Nueva York, Cornell University Press, 1989 (trad. al castellano de Ana Mendoza, Modernidad y Holocausto, Madrid, Sequitur, 1997).

Béjar, Helena: La cultura del yo. Pasiones colectivas y afectos propios en la teoría social, Madrid, Alianza, 1993.

Bénichou, Paul: Le sacre de l'écrivain, 1750-1830. Essai sur l'avènement d'un pouvoir spirituel laïque dans la France Moderne, París, Corti, 1973 (trad. al castellano de Aurelio Garzón del Camino, La coronación del escritor, 1750-1830. Ensayo sobre el advenimiento de un poder espiritual laico en la Francia moderna, México, Fondo de Cultura Económica, 1981).

Bénichou, Paul: Le temps des prophètes. Doctrines de l'âge romantique, París, Ga-

90. Tocqueville, Recuerdos de la Revolución de 1848, op. cit., p. 36.

91. Vid. Schenk, op. cit., p. 61. Bauman, Zygmunt: Modernity and the Holocaust, Ithaca, Nueva York, Cornell University Press, 1989 (trad. al castellano de Ana Mendoza, Modernidad y Holocausto, Madrid, Sequitur, 1997). 
llimard, 1977 (trad. al castellano de Aurelio Garzón del Camino, El tiempo de los profetas. Doctrinas de la época romántica, México, Fondo de Cultura Económica, 1984).

Berlin, Isaiah: The Crooked Timber of Humanity: Chapters in the History of Ideas, Londres, John Murray, 1990 (trad. al castellano de José Manuel Álvarez Flórez, El fuste torcido de la humanidad. Capítulos de historia de las ideas, Barcelona, Península, 1992).

Bonnefoy, Yves: Goya, les peintures noires, Burdeos, William Blake \& Co., 2006 (trad. al castellano de Patricia Martínez, Goya. Las pinturas negras, Madrid, Tecnos, 2018).

Cabanis, Pierre-Jean-Georges: Quelques considérations sur l'organisation sociale en général, et particulièrement sur la nouvelle Constitution, Commission du Conseil des Cinq-cents, París, Imprimerie Nationale, Frimario año VIII (1799).

Cassese, Sabino: // diritto amministrativo: storia e prospettive, Milán, Giuffrè Editore, 2010 (trad. al castellano: Derecho Administrativo: Historia y futuro, Madrid, Instituto Nacional de Administración PúblicaEditorial Derecho Global, 2014).

Craiutu, Aurelian: Liberalism under Siege: The Political Thought of the French Doctrinaires, Lanham, Maryland, Lexington Books, 2003 (trad. al francés de Isabelle Hausser : Le Centre introuvable. La pensée politique des doctrinaires sous la Restauration, París, Plon, 2006).

Delgado Fernández, Santiago y Jiménez Díaz, José Francisco: "Introducción. Los antecedentes: Las ideas políticas de los ilustrados en el contexto europeo. 4.- Ilustración alemana: el pensamiento político de Immanuel Kant", en Delgado Fernández, Santiago y Jiménez Díaz, José Francisco (eds.): Introducción a la Historia de las Ideas políticas Contemporáneas, Gra- nada, Universidad de Granada, 2008, pp. 11-35.

Díez Del Corral, Luis: El liberalismo doctrinario, Madrid, Centro de Estudios Constitucionales, $4^{a}$. ed., 1984 [1 $1^{a}$ ed. 1945].

Droz, Jacques: Europe between Revolutions, 1815-1848, Londres, Collins Sons, 1967 (trad. castellano de Ignacio Romero de Solís, Europa: Restauración y Revolución, 1815-1848, Madrid, Siglo XXI, $11^{a}$ ed., 1993 [1 $1^{a}$ ed. 1974]).

Finkielkraut, Alain: La défaite de la pensée, París, Gallimard, 1987 (seguimos la traducción en castellano de Joaquín Jordá, La derrota del pensamiento, Barcelona, Anagrama, $5^{a}$ edición, septiembre de 1994 [1ª ed. octubre 1987]).

García Guatas, Manuel: Jean Auguste Dominique Ingres, Madrid, Historia16, El arte y sus creadores, n. 32, 1993.

Girard, Louis : Les libéraux français, 18141875, París, Aubier, 1985.

González Cuevas, Pedro Carlos: Historia de las derechas españolas. De la Ilustración a nuestros días, Madrid, Biblioteca Nueva, 2000.

Guillemin, Henri: Silence aux pauvres! Libelle, París, Arléa, 1989 (trad. al castellano por Juan Vivanco, ¡Los pobres, a callar! Libelo, Barcelona, Grijalbo Mondadori, 1997).

Guizot, François: De la démocratie en France, París, Plon-Víctor Masson, 1849 (traducción, introducción y notas de Dalmacio Negro Pavón, De la democracia en Francia, Madrid, Centro de Estudios Constitucionales, 1981).

Guizot, François: Histoire des origines du gouvernement représentatif en Europe, París, Didier, 2 vols., 1851 (trad. al castellano en un volumen de Marceliano Acevedo Fernández, Historia de los orígenes del gobierno representativo en Europa, Oviedo, KRK, 2009). 
Guizot, François: Histoire parlementaire de France, Recueil complet des discours prononcés dans les Chambres de 1819 à 1848 par M. Guizot, París, Michel Lévy Frères, t. III, 1863.

Hazard, Paul: La crise de conscience européenne, 1680-1715, París, A. Fayard, 1961 (trad. al castellano de Julián Marías, La crisis de la conciencia europea (16801715), Madrid, Alianza, 1988).

Hegel, Georg Wilhelm Friedrich: Fundamentos de la Filosofía del Derecho o Compendio de Derecho Natural y Ciencia Política, edición, traducción, estudio preliminar y notas de Joaquín Abellán, Madrid, Tecnos, 2017.

Herrero, Javier: Los orígenes del pensamiento reaccionario español, Madrid, Cuadernos para el diálogo-Edicusa, 1973. Innerarity, Daniel: Hegel y el romanticismo, Madrid, Tecnos, 1993.

Jaume, Lucien: "El liberalismo posrevolucionario: Francia e Inglaterra", en Robledo, Ricardo; Castells, Irene; Romeo, $\mathrm{M}^{\mathrm{a}}$ Cruz (eds.): Orígenes del Liberalismo. Universidad, Política, Economía, Salamanca, Universidad de Salamanca-Junta de Castilla y León, 2003, pp. 143-153.

Jaume, Lucien: "Le libéralisme français après la Révolution, compare au libéralisme anglais", en Historia Constitucional, n. 4 (2003), pp. 383-393.

Jaume, Lucien: L'individu effacé ou le paradoxe du libéralisme français, París, Fayard, 1997.

Kant, Immanuel: La paz perpetua, Madrid, Tecnos, trad. al castellano de Joaquín Abellán, 2ª ed., 1989.

Lacchè, Luigi: "Constitución, monarquía, parlamento: Francia y Bélgica ante los problemas y modelos del constitucionalismo europeo (1814-1848)", en Fundamentos, $n^{\circ} .2$ (2000), pp. 467-543.
Lacchè, Luigi: La Libertà che guida il Popolo. Le Tre Gloriose Giornate del Iuglio 1830 e le "Chartes» nel costituzionalismo francese, Bolonia, II Mulino, 2002.

Lacchè, Luigi: "Las Cartas Otorgadas. La teoría de l'octroi y las experiencias constitucionales en la Europa post-revolucionaria", en Fundamentos, n. 6 (2010), pp. 269-305.

Laquièze, Alain: Les origines du régime parlementaire en France (1814-1848), París, Presses Universitaires de France, 2002.

Lario, Ángeles: "La Corona en el Estado liberal. Monarquía y Constitución en la España del siglo XIX", en Historia Contemporánea, no. 17 (1998), pp. 139-157.

Lario, Ángeles: "Monarquía Constitucional y Gobierno Parlamentario", en Revista de Estudios Políticos, $\mathrm{n}^{\circ} 106$ (octubrediciembre 1999), pp. 277-288.

Lesmes, Daniel: Aburrimiento y capitalismo. En la escena revolucionaria: París, 1830-1848, Madrid, Pre-Textos, 2018.

Lista, Alberto: "Constitution de la nation française, avec un essai de traité et un recueil de pièces correlatives; par le comte Lanjuinais, pair de France, membre de I'Institut, etc. 1819", en El Censor, t. I, nº. 2 (12 de agosto de 1820), pp. 110-119.

Lista, Alberto: "Continúa el discurso anterior", en El Espectador Sevillano, n. 50 (20 de noviembre de 1809), pp. 197-200.

Lista, Alberto: "De la dictadura", en El Censor, t. XI, núm. 62 (6 de octubre de 1821), pp. 81-104.

Lista, Alberto: "Del fanatismo servil", en El Censor, t. XVII, n. 101 (6 de julio de 1822), pp. 321-341.

Lista, Alberto: "Del fanatismo y de la intolerancia, su compañera inseparable", en El Censor, t. IX, n .49 (7 de julio de 1821), pp. 54-75. 
Lista, Alberto: "Italia", en El Censor, t. IV, no. 21 (23 de diciembre de 1820), pp. 180-209.

López Calera, Nicolás María: El riesgo de Hegel sobre la libertad, Granada, Universidad de Granada, 1973.

Maritain, Jacques: The Range of Reason, Nueva York, Scribner, 1952 (trad. al castellano de Alberto Luis Bixio, El alcance de la razón, Buenos Aires, Emecé, 1959).

Martínez Torrón, Diego: El alba del romanticismo español, Sevilla, Alfar-Universidad de Córdoba, 1993.

Marx, Karl: Las luchas de clases en Francia de 1848 a 1850, Madrid, trad. A. S. Cuper, Austral, $2^{\mathrm{a}}$ ed., 1992.

Mathiez, Albert: Les origines des cultes révolutionnaires (1789-1792), París, Société Nouvelle de Librairie et d'édition, 1904 (seguimos la edición, traducción, estudio preliminar y notas de Francisco Javier Ramón Soláns, Los orígenes de los cultos revolucionarios (1789-1792), Zaragoza, Prensas de la Universidad de Zaragoza, 2012).

Maurois, André: Histoire de la France, París, Wapler, 1947 (trad. al castellano de María Luz Morales, Historia de Francia, Barcelona, Círculo de Lectores, 1973).

Mavida, M.J. ; Laurent, M.L. (fond.) ; Barbier, G. ; Claveau, L. ; Lataste, L. ; Pionnier, C. (dir.) : Archives parlementaires de 1787 à 1860, Recueil complet des débats législatifs et politiques des Chambres françaises, Deuxième série (1800 à 1860), t. CXXIII, París, Dupont, 1911.

Mayer, Arno J.: The Furies.Violence and Terror in the French and Russian Revolutions, Princeton and Oxford, Princeton University Press, 2000 (trad. al castellano de Víctor Lucea Ayala, Las Furias: violencia y terror en las revoluciones francesa y rusa, Zaragoza, Prensas de la Universidad de Zaragoza, 2014).
Melegari, Dora (ed.), Journal intime de Benjamin Constant et lettres à sa famille et à ses amis, París, Albin Michel, 1928 [1ª. ed., París, Ollendorff, 1895].

Peces-Barba, Gregorio y Dorado Porras, Javier: "Derecho, Sociedad y Cultura en el siglo XVIII", en Peces-Barba Martínez, Gregorio; Fernández García, Eusebio; y De Asís Roig, Rafael (dir.): Historia de los Derechos fundamentales, t. II: siglo XVIII, Vol. I: El contexto social y cultural de los derechos. Los rasgos generales de evolución, Madrid, Dykinson-Instituto de Derechos Humanos Bartolomé de las CasasUniversidad Carlos III, 2001, pp. 3-219.

Ponteil, Félix: 1848, París, Armand Colin, 1837 (trad. al castellano de Jesús CasteIlote López, La Revolución de 1848, Madrid, Zyx, 1966).

Portillo Valdés, José María: Revolución de nación. Orígenes de la cultura constitucional en España, 1780-1812, Madrid, Centro de Estudios Políticos y Constitucionales, 2000.

Riezu Martínez, Jorge: "La teoría política de Hegel", en en Delgado Fernández, Santiago y Jiménez Díaz, José Francisco (eds.): Introducción a la Historia de las Ideas políticas Contemporáneas, Granada, Universidad de Granada, 2008, pp. 81-95.

Rosanvallon, Pierre: La Monarchie impossible. Les Chartes de 1814 et de 1830, París, Fayard, 1994.

Rosanvallon, Pierre : Le modèle politique français. La société civile contre le jacobinisme de 1789 à nos jours, París, Ed. du Seuil, 2004 (trad. al castellano de Víctor A. Goldstein, El modelo político francés: la sociedad civil contra el jacobinismo, de 1789 a nuestros días, Buenos Aires, Siglo XXI, 2007).

Rosanvallon, Pierre: Le moment Guizot, París, Gallimard, 1985, (trad. al castellano 
de Hernán M. Díaz, El momento Guizot. El liberalismo doctrinario entre la Restauración y la Revolución de 1848, Buenos Aires, Biblos, 2015).

Rosanvallon, Pierre: Le sacre du citoyen. Histoire du suffrage universel en France, París, Gallimard, 1992 (trad. al castellano de Ana García Bergua, La consagración del ciudadano. Historia del sufragio universal en Francia, México, Instituto Mora, 1999).

Rosanvallon, Pierre: "Les Doctrinaires sont-ils des libéraux?", en Darío Roldán (ed.), Guizot, les Doctrinaires et la presse (1820-1830), Val-Richer, Fondation François Guizot-Val Richer, 1994, pp. 133139.

Rudler, Gustave: La Jeunesse de Benjamin Constant, 1767-1794. Le disciple du XVIIle siècle. Utilitarisme et pessimisme. Mme. de Charrière. D'après de nombreux documents inédits, París, Armand Colin, 1909.

Sánchez-Mejía, María Luisa: Benjamín Constant y la construcción del liberalismo posrevolucionario, Madrid, Alianza, 1992.

Sánchez-Mejía, María Luisa (ed.), Cabanis y Destutt de Tracy. Textos políticos de los Ideólogos, Madrid, Centro de Estudios Políticos y Constitucionales, 2004.

Sánchez-Mejía, María Luisa: “Desencanto político y nostalgia del paraíso en los orígenes del "mal du siècle" ", en Thélème: Revista complutense de estudios franceses, n. 9 (1996), pp. 247-262.

Sánchez-Mejía, María Luisa: "Madame de Staël y la Constitución del año III: el nacimiento del republicanismo liberal", en Historia Constitucional, n. 16 (2015), pp. 47-66.

Sánchez-Mejía, María Luisa: "Repúblicas monárquicas y Monarquías republicanas. Las reflexiones de Sieyès, Necker y Constant sobre las formas de gobierno", en Revista de Estudios Políticos, n 120 (abril-junio 2003), pp. 195-217.

Schenk, H. G.: The Mind of the European Romantics. An Essay in Cultural History, Londres, Constable \& Co., 1966 (trad. al castellano por Juan José Utrilla, El espíritu de los románticos europeos. Ensayo sobre historia de la cultura, México, Fondo de Cultura Económica, 1983).

Siedentop, Larry: "Two Liberal Traditions", en Alan Ryan (ed.), The Idea of Freedom, Oxford, Oxford University Press, 1979, pp. 153-174.

Sprute, Jürgen: Filosofía política de Kant, Madrid, Tecnos, 2008.

Starobinski, Jean: 1789. Les Emblèmes de la Raison, París, Flammarion, 1973 (trad. al castellano de José Luis Checa Cremades, 1789, los emblemas de la razón, Madrid, Taurus, 1988).

Steiner, George: In Bluebeard's Castle: Some notes towards the redefinition of culture, New Haven, Yale University Press, 1971 (trad. al castellano de Alberto L. Budo, En el castillo de Barba Azul. Aproximación a un nuevo concepto de cultura, Barcelona, GEDISA, 2ª ed., 1992 [1 ${ }^{a}$ ed. en 1991]).

Subirats, Eduardo: Metamorfosis de la cultura moderna, Barcelona, Anthropos, 1991.

Takeda, Chinatsu: "Deux origines du courant libéral en France", en Revue Française d'Histoire des Idées Politiques, 2003 ( $2^{\circ}$ semestre), $n^{\circ}$. 18: Les Ideólogues et le Groupe de Coppet, pp. 233-257.

Tocqueville, Alexis de: Souvenirs, París, Calmann Lévy, 1893 (trad. al castellano de Marcial Suárez, Recuerdos de la Revolución de 1848, Madrid, Trotta, 1994).

Tocqueville, Mme. de (ed.), Euvres complètes d'Alexis de Tocqueville, t. IX: Études économiques, politiques et littéraires par Alexis de Tocqueville, París, Michel Lévy, 1866. 
Touchard, Jean: Histoire des idées politiques, París, Presses universitaires, 1959 (trad. al castellano de J. Pradera, Historia de las ideas políticas, Barcelona, Círculo de Lectores, t. II, 1990).

Varela Suanzes-Carpegna, Joaquín: "El liberalismo francés después de Napoleón (De la Anglofobia a la Anglofilia)", en Revista de Estudios Políticos, $\mathrm{n}^{\circ}$. 76 (abriljunio 1992), pp. 29-43.

Vivanco, Luis Felipe: Moratín y la Ilustración mágica, Madrid, Taurus, 1972.

Vovelle, Michel: La mentalité révolutionnaire. Société et mentalités sous la RévoIution française, París, Messidor-Éditions Sociales, 1985 (trad. al castellano de Rafael Santamaría, La mentalidad revolucionaria, Barcelona, Crítica, 1989).

Woronoff, Denis: La République Bourgeoise. De Thermidor à Brumaire, 17941799, París, Éditions du Seuil, 1972 (trad. al castellano de Javier Alfaya, La República Burguesa. De Termidor a Brumario 1794-1799, Barcelona, Ariel, 1981).

Zambrano, María: Horizonte del liberalis-

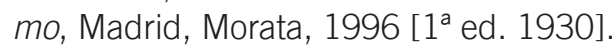

